\title{
COVID-Induced Investor Sentiments and Market Reaction under Extreme Meteorological Conditions: Evidence from Clean Energy Sector of Asia-Pacific
}

\author{
Nastroje inwestorów wywołane przez COVID-19 i reakcje \\ rynku w ekstremalnych warunkach meteorologicznych: \\ dowody z sektora czystej energii w regionie Azji i Pacyfiku
}

\section{Farzan Yahya*, Zhang Shaohua**, Muhammad Waqas***, Zhengde Xiong ${ }^{\star \star \star *}$}

\author{
*Corresponding Author: Department of Business Administration, Institute of Southern \\ Punjab, 9-KM, Bosan Road, Khayab-e-Yusuf, Multan, Pakistan \\ E-mail: farzan.yahya@yahoo.com \\ ORCID: 0000-0001-5666-1279 \\ ** School of Economics \& Statistics, Guangzhou University, China \\ E-mail:ahua168@126.com \\ *** School of Management, Jiangsu University, China \\ E-mail:mwaqas@mail.ustc.edu.cn \\ **** School of Business Administration, Hunan University, Changsha, China \\ E-mail:hnxzd@126.com
}

\begin{abstract}
The unprecedented global economic and social crisis caused by the coronavirus outbreak has not spared the energy sector. Using a dynamic model, we investigated the effect of COVID-19 cases on investor sentiments and stock returns of clean energy in the Asian-Pacific region. The results show that coronavirus cases negatively affect stock returns using investor sentiments as a transmission channel. We also find a negative effect of air pollution on stock returns. Since COVID-19 restricted trade and plummeted the oil prices, economies relied on non-renewable sources to meet energy demands. Nevertheless, the investor's optimism and high sentiment level may deteriorate this link. On the other hand, we do not find any significant effect of low-high temperature on either investor sentiments or clean energy stock returns. Clean energy stocks were viewed as more sustainable and less vulnerable to external shocks, however, the fear and pessimism among investors induced by coronavirus are spilled over the renewable energy sector.
\end{abstract}

Key words: COVID-19, investor sentiments, air pollution, temperature, clean energy stocks

\section{Streszczenie}

Bezprecedensowy globalny kryzys gospodarczy i społeczny wywołany wybuchem koronawirusa uderzył także w sektor energetyczny. Korzystając z modelu dynamicznego, zbadaliśmy wpływ COVID-19 na nastroje inwestorów i stopy zwrotu w sektorze czystej energii w regionie Azji i Pacyfiku. Odkąd COVID-19 wpłynął negatywnie na handel i przyczynił się do gwałtownego spadku ceny ropy, wiele gospodarek wsparło odnawialne źródła energii, aby zaspokoić zapotrzebowanie na energię. Wyniki pokazują jednak, że koronawirus negatywnie wpływa na stopy zwrotu. Stwierdzamy również negatywny wpływ zanieczyszczenia powietrza na stopy zwrotu. Z drugiej strony nie widzimy istotnego wpływu zmian temperatury ani na nastroje inwestorów, ani na stopy zwrotu z czystej energii. Akcje czystej energii były postrzegane jako bardziej zrównoważone i mniej podatne na wstrząsy zewnętrzne, 
jednak strach i pesymizm inwestorów wywołany koronawirusem może wpłynąć negatywnie na sektor energii odnawialnej.

Słowa kluczowe: COVID-19, nastroje inwestorów, zanieczyszczenia powietrza, temperatura, rynek energii odnawialnej

\section{Introduction}

The coronavirus outbreak has triggered an unprecedented human health, social, and economic crisis. It largely threatens global financial stability due to uncertainty about its persistence and intensity (Sohrabi et al., 2020). The stringent lockdown policies have halted the economic activities in the short-run while its impact on financial distress, business failures, and unemployment can be observed in the long-run (Coibion, Gorodnichenko, \& Weber, 2020). Asset prices have dramatically fallen, market liquidity has jeopardized while volatility and credit spreads have spiked that plunged the investor confidence since the pandemic's outbreak (Liu, Manzoor, Wang, Zhang, \& Manzoor, 2020). Even safer investments have faced losses when the virus moved from China to western countries (Ali, Alam, \& Rizvi, 2020).

In the wake of the pandemic, researchers have shifted their focus to evaluate the effect of the COVID-19 outbreak on the trajectories of sustainability transitions (Cohen, 2020; Kanda \& Kivimaa, 2020). The pandemic has underpinned the importance of energy in the social order with the facility shutdown, mobility disruption, and shift to digital modes of remote work. On one hand, the drop in electricity demands open doors for the use of sustainable energy due to a reduction in the need to meet the energy demands of industries through non-renewable energy sources (Birol, 2020). On the other hand, the trade and delivery of many renewable energy technologies such as batteries, wind turbines, and solar panels were delayed by the Chinese producers which induced investors' pessimism, fear and uncertainty toward sustainable energy (Kanda \& Kivimaa, 2020; Mylenka \& Novyk, 2020). The reason being the severity and scale of this unprecedented situation is not recognized, investor sentiments and their cognitive biases have affected even the sustainable portfolios while essential investments are gaining more attention.

In tandem to prior literature, the assumptions of the classical market efficient hypothesis failed to justify the sentiments and irrationalities of investors especially during uncertain events (Hens \& Riege, 2016). Extreme investor sentiments along with their noise trading have emerged as a systematic risk factor for the global capital markets (Qiang \& Shu-e, 2009). These investor sentiments are generally hard to arbitrage and difficult to value particularly in the shortrun (Baker \& Wurgler, 2006). Prior studies revealed that unanticipated events, meteorological conditions and news shocks such as extreme weather (Apergis, Gabrielsen, \& Smales, 2016), the higher level of air pollution (Lepori, 2016; Li, \& Peng, 2016), daylight saving (Kamstra, Kramer, \& Levi, 2000), terrorist attacks (Papakyriakou, Sakkas, \& Taoushianis, 2019), natural disasters (Bourdeau-Brien, \& Kryzanowski, 2017), epidemics and pandemics (Al-Awadhi, AlSaifi, Al-Awadhi, \& Alhamadi, 2020; Ichev \& Marinč, 2018) may shift investor sentiments and their behavioral biases result in a higher level of stock market volatility.

Although the absolute circumstances of the economic downturn due to COVID-19 are still underexplored, it is evident that the major stock markets have hit the circuit break mechanism and market indexes plunged up to 20-30 percent (Zhang, Hu, \& Ji, 2020). Considering the fresh evidence to support our empirical model, researchers have revealed the negative effect of confirmed and death cases due to coronavirus on the stock market (Akhtaruzzaman, Boubaker, \& Sensoy, 2020; Al-Awadhi et al., 2020; Ali et al., 2020; Liu et al., 2020; Zhang et al., 2020). Nevertheless, to the best of our knowledge, studies have not explored the effect of COVID-19 on the renewable energy sector, especially in the Asian-Pacific context.

The energy sector is also largely affected after coronavirus outbreak with the plummeting prices and production of oil and electricity (IEA, 2020). Energy consumption has reduced to $12 \%$ in the UK, $20 \%$ in France and $25 \%$ in Italy. The renewable energy sector of China profoundly faced detrimental effects of the pandemic due to the non-delivery of equipment to power plants. Around 3,000 MW of renewable energy projects are postponed in India alone due to failure in the supply of batteries, wind turbines, and solar panels (Mylenka \& Novyk, 2020). Since both developing and developed countries are thriving for their survival, the green agenda seems to be largely compromised. Thus, it is important to examine how the coronavirus outbreak has effected the green stocks. Although Albuquerque, Koskinen, Yang, and Zhang (2020) revealed that sustainable and environmental stocks show more resilience during the COVID-19 market crash with higher operating profit margins, lower return volatility, and higher investor returns, more empirical evidence especially in the context of Asian-Pacific region is required.

Several theoretical contributions can be derived from the current study. First, our study fills the void in the current clean energy literature by investigating the effect of COVID-19 on firm-level investor sentiments after controlling for different meteorological factors, calendar anomalies, and country-specific variables. Economic uncertainty and external shocks fueled by stringent economic conditions due to this 
fast-spreading contagious disease have shifted the investor's sentiments. Financial crises create anxiety, bad mood, pessimism, and risk-aversion among investors that lead to bullish trend and negative asset returns (Kaplanski \& Levy, 2010; Li et al., 2020). Secondly, we investigate the effect of COVID-induced investor sentiments on daily stock returns of renewable energy firms under low-high temperature or low-high air pollution. The purpose of testing the second model is to examine if extreme meteorological conditions further fuel low-high investor sentiments that reflect the daily stock returns.

Prior studies have associated extreme temperature with investors' mood swings, anxiety and seasonal affective disorder (SAD) which lead to somber investor sentiments, less risk-taking behavior and lower stock returns (Apergis, Gabrielsen, \& Smales, 2016; Dowling \& Lucey, 2008; Floros, 2011; Sheikh, Shah, \& Mahmood, 2017). Similarly, air pollution has emotional and biophysical effects that exhibit lower liquidity, stock returns, and volatility due to depressed and pessimistic moods (Ding, Guo, \& Yang, 2020; Lepori, 2016; Li, \& Peng, 2016. Wu, Hao, \& Lu, 2018). Generally, it is believed that irrationalities and behavioral anomalies are stronger in bullish markets when investor sentiments are high (Stambaugh, Yu, \& Yuan, 2012). Although mispricing can be adjusted in the long-run and investor gain low realized returns after a high sentiment period, the sentiment is positively associated with short-term realized gains (Seok, Cho, \& Ryu, 2019). Considering a short-time period since coronavirus outbreak, we believe that the effect of COVID-induced pessimistic investor sentiments may further prompt riskaversion when investors face extreme temperatures or higher levels of air pollution.

The rest of the paper proceeds as follows: Section 2 exhibits research methodology including data, sample, measurements, and empirical model used to investigate our study's objectives. Section 3 outlines results and discussion. Finally, we conclude the study in the last section.

\section{Methodology}

\subsection{Data and Sample}

We collected the data of renewable energy firms producing biomass, geothermal, hydropower, wind, and solar energy equipment listed on stock exchanges of Asian-Pacific countries. There are 47 countries in the Asian-Pacific region but we consider only those economies in the sample where at least 5 renewable

\footnotetext{
${ }^{1}$ We excluded all those power generating firms that are producing majority of energy/electricity from non-renewable energy sources despite their production of renewable energy.

2 Tradable A shares listed on Shanghai Securities Exchange and the Shenzhen Stock Exchange.
}

energy firms ${ }^{1}$ are functional and listed on their respective stock exchanges. The final sample includes 52 firms from $\mathrm{China}^{2}$, 19 firms from India, 5 firms from Japan, 5 from Vietnam, 5 from Thailand, 7 from South Korea, 6 from Malaysia, and 6 from Australia.

Data on daily share prices and the foreign exchange rate were retrieved from the Bloomberg database over the period December $31^{\text {st }} 2019^{3}$ to May $31^{\text {st }}$ 2020. The data of the confirmed cases, death cases, and recovered cases from COVID-19 were collected from the Humanitarian Data Exchange for the same period. Unlike Al-Awadhi et al. (2020), we have utilized the growth of confirmed active coronavirus cases $^{4}$ rather than new confirmed cases. Temperature related data (in Celsius) was collected from Weather Underground while $\mathrm{PM}_{2.5}$ data from aqicn.org. The data of temperature and air pollution is collected for the cities where relevant stock exchanges of the countries are located, i.e. Shanghai, Mumbai, Ho Chi Minh, Bangkok, Busan, Kuala Lumpur, and Sydney. Although air quality index is a better measurement of detecting air pollution in a region, the daily AQI data for all countries is not available. Since data of GDP per capita and electricity production for the year 2020 was not available during the period we conducted the study, we relied on the 2019 figures provided by the CEIC database.

\subsection{Measurement}

On grounds of testing two models to achieve our objectives, investor sentiment is the dependent variable in the first model and daily stock return in the second model. We utilized the method of Seok et al. (2019) to develop the firm-level investor sentiment index. This index is more efficient in the context of emerging markets as it based on daily stock prices. Alterative proxies for investor sentiments include logarithm of trading volume (LTV), adjusted turnover rate (ATR), psychological line index (PLI), and relative strength index (RSI) which were combined using the principal component analysis to develop the investor sentiment index ${ }^{5}$.

In order to divide the sample into high and low sentiments, we considered the criteria used by $\mathrm{Bi}$ and Zhu (2020). If the investor sentiment index is larger than its mean (or one standard deviation above its mean), then investor sentiments are high and low sentiments were characterized as one standard deviation below the index's mean. On the other hand, we used two standard deviation below/above the values of temperature or air pollution to classify low-high meteorological conditions. The value local country's

\footnotetext{
${ }^{3}$ Since the first case of coronavirus was registered on $31^{\text {st }}$ December 2019 in Wuhan, China.

${ }^{4}$ We subtracted confirmed recovered and death cases from new confirmed cases to evaluate confirmed active cases.

${ }^{5}$ To understand the technical details of index development and information on individual proxies, refer to Seok et al. (2019).
} 
currency in relation to US dollars was utilized for the foreign exchange rate, e.g. RMB/USD for China. Electricity production and GDP per capita were logtransformed to mitigate any non-normality issue. Lastly, we entered weekend and turn-of-the-month effect to account for calendar anomalies. The concept of weekend effect (also known as Monday effect) emerged after the findings of Cross (1973) who revealed a lower level of returns on Monday compared to other days of the week. The weekend effect may persist due to short-selling or bad news releases by the firms on Friday. Turn-of-the-month (TOM) effect is also a behavioral anomaly when stock prices go up temporarily during the first and last few days of each possibly due to reinvestment of pension funds to the stock market by the pensioners. These calendar anomalies are measured using dummy variables, i.e. $1=$ Monday, $0=$ otherwise for weekend effect, and 1 = last two and first two trading days of the month, $0=$ otherwise for TOM effect.

\subsection{Model Specification}

Classical event analysis techniques cannot be utilized during the peak of a pandemic, therefore, panel data analysis techniques are most suitable to investigate the effect of COVID-19 on investor sentiment or stock market return. Panel data technique also mitigates the issues related to estimation bias, heteroscedasticity, and multicollinearity (Woolridge 2010). To investigate the time-varying relationship of confirmed active cases with investor sentiments, we developed the following model:

$\mathrm{INS}_{\mathrm{it}}=\alpha_{\mathrm{i}}+\beta_{1}$ COVID $_{\mathrm{i}, \mathrm{t}-1}+\beta_{2} \mathrm{AIR}_{\mathrm{it}}+\mathrm{B}_{3} \mathrm{TEMP}_{\mathrm{it}}+$ $\beta_{4} \mathrm{CF}_{\text {it }}+\beta_{5} \mathrm{CA}_{\text {it }}+\beta_{6} \mathrm{FED}_{\text {it }}+\varepsilon_{\text {it }}$

Where INS is the investor sentiments, COVID is the daily confirmed active cases, AIR is the air pollution, TEMP denotes temperate, $\mathrm{CF}$ is the country-specific variables, i.e. foreign exchange rate, $\log$ of GDP and electricity consumption, $\mathrm{CA}$ is the calendar anomalies including weekend and TOM effect, FED is the daily fixed-effect variables that includes month dummy, country dummy, and Asian-pacific sub-region dummy ${ }^{6}$ to mitigate heteroscedasticity and $\varepsilon$ is an error term. The subscripts $i$ and $t$ represent firm and day respectively while $\alpha$ is the constant term. Heteroskedastic-robust standard errors were used to estimate p-values in regressions. On the other hand, we considered daily stock return as a dependent variable in the second model to estimate COVID-induced investor sentiments on stock market returns of clean energy firms:

$\mathrm{DR}_{\mathrm{it}}=\alpha_{\mathrm{i}}+\beta_{1}$ COVID $_{\mathrm{i}, \mathrm{t}-1}+\beta_{2} \mathrm{INS}_{\mathrm{it}}+\beta_{3}$ COVID $\mathrm{INS}_{\mathrm{it}}$ $+\beta_{4} \mathrm{AIR}_{\mathrm{it}}+\mathrm{B}_{4} \mathrm{TEMP}_{\mathrm{it}}+\beta_{6} \mathrm{CF}_{\mathrm{it}}+\beta_{7} \mathrm{CA}_{\mathrm{it}}+\beta_{8} \mathrm{FED}_{\mathrm{it}}+$ $\varepsilon_{\text {it }}$

Where DR is the daily stock return. Investor sentiment and its interaction with active coronavirus cases were incorporated as explanatory variables in equation 2. Nevertheless, it is important to note that prior studies (Al-Awadhi et al., 2020; Ali et al., 2020 Ashraf, 2020) ignored the possibility of the dynamic relationship while examining the stock market reaction to COVID-19. The strict exogeneity of regressors cannot be presumed valid when the lagged dependent variable significantly explains the underlying dependent variable. Consequently, the following dynamic model was developed:

$\mathrm{INS}_{\mathrm{it}}=\alpha_{\mathrm{i}}+\beta_{1} \mathrm{INS}_{\mathrm{i}, \mathrm{t}-1}+\beta_{2} \mathrm{COVID}_{\mathrm{i}, \mathrm{t}-1}+\beta_{3} \mathrm{AIR}_{\mathrm{it}}+$

$\beta_{4} \mathrm{TEMP}_{\mathrm{it}}+\beta_{5} \mathrm{CF}_{\mathrm{it}}+\beta_{6} \mathrm{CA}_{\mathrm{it}}+\beta_{7} \mathrm{FED}_{\mathrm{it}}+\varepsilon_{\mathrm{it}}$

$\mathrm{DR}_{\mathrm{it}}=\alpha_{\mathrm{i}}+\beta_{1} \mathrm{DR}_{\mathrm{i}, \mathrm{t}-1}+\beta_{2} \mathrm{COVID}_{\mathrm{i}, \mathrm{t}-1}+\beta_{3} \mathrm{INS}_{\mathrm{it}}+\beta_{4} \mathrm{CO}-$ $\mathrm{VID}^{*} \mathrm{INS}_{\mathrm{it}}+\beta_{5} \mathrm{AIR}_{\mathrm{it}}+\mathrm{B}_{6} \mathrm{TEMP}_{\mathrm{it}}+\beta_{7} \mathrm{CF}_{\mathrm{it}}+\beta_{8} \mathrm{CA}_{\mathrm{it}}$ $+\beta_{9} \mathrm{FED}_{\mathrm{it}}+\varepsilon_{\mathrm{it}}$

Lagged values of dependent variables were entered in the equation 3 and 4 . Conventional panel data models such as random or fixed effect estimators may produce biased estimates in case of endogeneity (Baltagi, 2015). Additionally, ordinary least square (OLS) is usually upwardly biased while fixed-effect estimations are downwardly biased. Generalized Method of Moment (GMM) estimator may account for unobserved heterogeneity or endogeneity bias. We use system-GMM estimator rather than difference GMM as the latter may produce biased estimates in the presence of high persistency of the dependent variable (Alonso-Borrego \& Arellano, 1999). The two-step system GMM accepts less strict stationary assumption and deal efficiently with finite sample bias (Blundell \& Bond, 1998). However, we use only two lags for the system GMM with a collapsed instrument matrix suggested by Roodman (2009) to avoid the probability of false-positive results emerge from an excessive number of instruments due to longer periods.

\section{Findings and Discussion}

Summary statistics of dependent and independent variables are given in Table 1. Likewise other industries, the clean energy sector of Asia-Pacific gives negative returns to the investors due to the fall in overall energy demand during the pandemic. On average, low sentiments also show risk-aversion and pessimistic behavior of investors during the coronavirus crisis. The growth of recovered cases from COVID-19 is greater than death and new cases. Despite the claims that coronavirus is a blessing in disguise for air quality, the average level of air pollution is still harmful to human health in the Asian-Pacific region. On the other hand, the region has a moderate level of temperature.

The correlation results show a positive association between investor sentiments and stock returns that provide initial support to our proposition that stock movements can be explained by the optimism and pessimism of investors especially during the crisis

\footnotetext{
${ }^{6}$ Sub-regions include East Asia, South Asia, Southeast Asia and Oceania.
} 
Table 1. Summary Statistics and Correlation Matrix, authors' own work

\begin{tabular}{|l|c|c|c|c|c|c|c|c|}
\hline & Mean & S.D. & DR & INS & New & Death & Recov & Air \\
\hline Daily Returns & -0.0027 & 0.1404 & 1 & & & & & \\
\hline Investor Sentiment Index & 0.0692 & 0.1922 & 0.447 & 1 & & & & \\
\hline New Confirmed Cases & 0.0490 & 0.0974 & -0.106 & -0.025 & 1 & & & \\
\hline Death Cases & 0.0501 & 0.0912 & -0.081 & -0.003 & 0.503 & 1 & & \\
\hline Recovered Cases & 0.0687 & 0.1029 & 0.117 & 0.018 & 0.474 & 0.496 & 1 & \\
\hline Air Pollution & 63.0094 & 51.028 & -0.251 & -0.102 & -0.155 & -0.127 & 0.103 & 1 \\
\hline Temperature & 19.326 & 9.9507 & 0.027 & 0.006 & 0.097 & 0.083 & 0.059 & 0.164 \\
\hline
\end{tabular}

Table 2. Fixed-effect and Two-Step System GMM Estimations, authors' own work

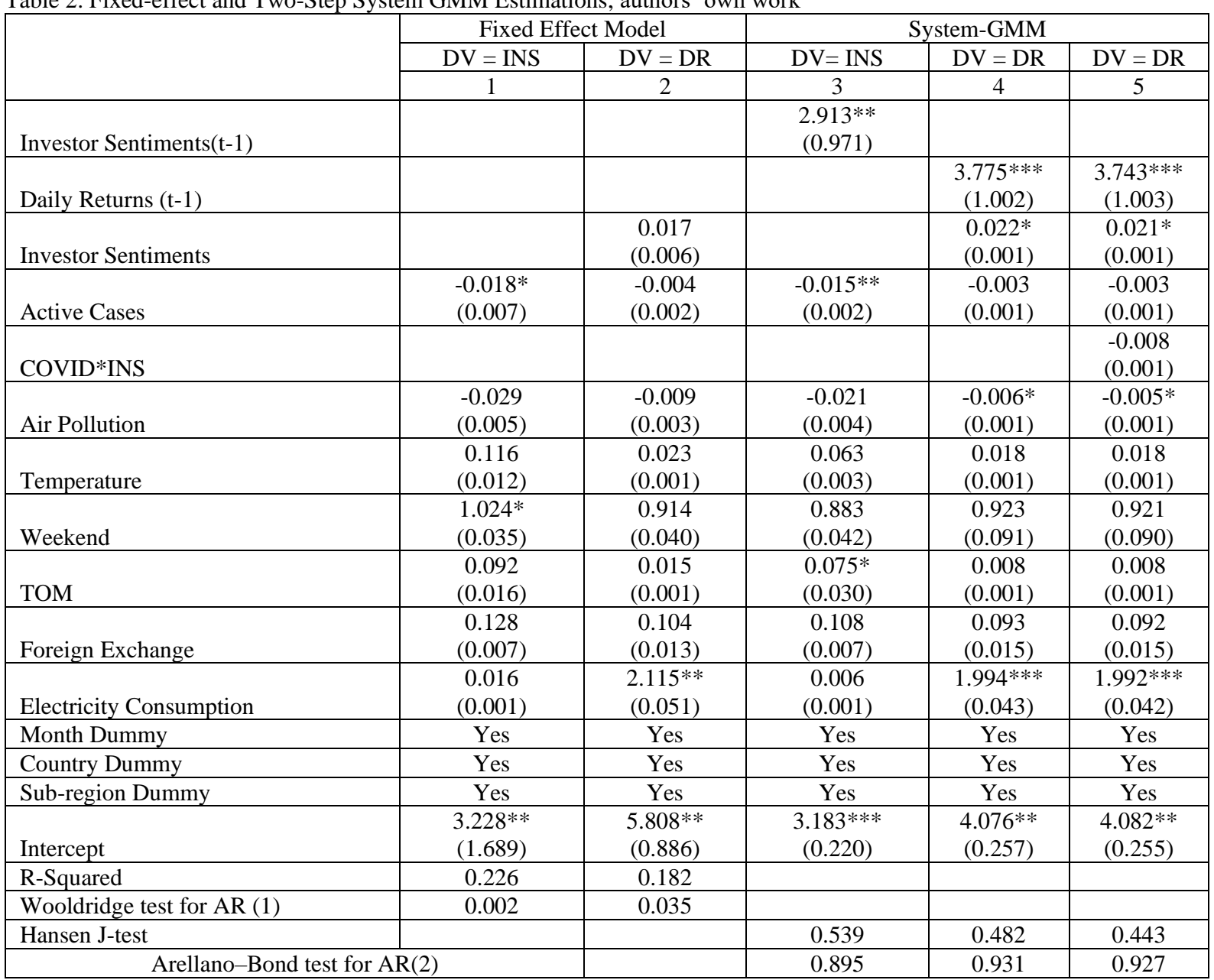

Note: DV = Dependent Variable, INS = Investor sentiments, DR = daily stock returns. Values in parenthesis are the robust standard errors. Hansen J-test refers to the over-identification test for the restrictions in GMM estimation. The AR2 test is the Arellano-Bond test for the existence of the second-order autocorrelation in first differences. *, **, and *** indicate significance at the $10 \%, 5 \%$, and $1 \%$ levels, respectively.

period. The negative correlation of new confirmed and death cases with daily returns and investor sentiments show that the fear and pessimism increase with the intensity of pandemic while recovered cases may yield hope among investors. A negative correlation between air pollution and stock returns implies the shift of investment for the clean energy sector to other industries with an increase in air pollution.

We started the regression analysis with a fixed-effect model, however, we preferred a two-step system GMM estimator due to the presence of an endogeneity issue. Table 2 illustrates that there is a significant and negative effect of active coronavirus cases on investor sentiments but no significant effect on daily returns. This implies that investor sentiments are a transmission channel for the impact of COVID-19 outbreak on stock returns. Similar evidence was evaluated by Liu et al. (2020) who used the S\&P 500 volatility index (VIX) to measure investors' fear/sentiments. Contrary to the conventional financial theory (e.g. efficient market hypothesis), our results are consistent with the behavioral finance perspective that there is a significant role of investor sentiment in the variation of equity returns (McGurk, Nowak, \& Hall, 2020). 
Table 3. Two-Step System GMM Estimations for Investor Sentiments Model, authors' own work

\begin{tabular}{|l|c|c|c|c|}
\hline & Low AIRP & High AIRP & Low TEMP & High TEMP \\
\cline { 2 - 5 } & 1 & 2 & 3 & 4 \\
\hline \multirow{3}{*}{ Investor Sentiments(t-1) } & $2.822^{*}$ & $2.762^{*}$ & $2.916^{* *}$ & $2.921^{*}$ \\
Active Cases & $(0.064)$ & $(0.057)$ & $(0.117)$ & $(0.218)$ \\
\hline & $-0.005^{*}$ & $-0.007^{*}$ & $-0.004^{*}$ & $-0.003^{* *}$ \\
Air Pollution & $(0.002)$ & $(0.002)$ & $(0.001)$ & $(0.001)$ \\
\hline & & & -0.008 & -0.003 \\
Temperature & & & $(0.001)$ & $(0.001)$ \\
\hline & 0.066 & -0.072 & & \\
Weekend & $(0.003)$ & $(0.002)$ & & 0.851 \\
& 0.873 & 0.885 & 0.836 & $(0.065)$ \\
\hline TOM & $(0.099)$ & $(0.190)$ & $(0.138)$ & $0.072^{* *}$ \\
Foreign Exchange & 0.071 & $0.073^{*}$ & $0.077^{*}$ & $(0.011)$ \\
\hline & $(0.012)$ & $(0.010)$ & $(0.012)$ & 0.105 \\
Electricity Consumption & 0.097 & 0.101 & 0.099 & $(0.009)$ \\
\hline Month Dummy & $(0.011)$ & $(0.042)$ & $(0.007)$ & 0.006 \\
\hline Country Dummy & 0.009 & 0.005 & 0.008 & $(0.002)$ \\
\hline Sub-region Dummy & $(0.001)$ & $(0.001)$ & $(0.001)$ & Yes \\
\hline Intercept & Yes & Yes & Yes & Yes \\
\hline Hansen J-test & Yes & Yes & Yes & Yes \\
\hline Arellano-Bond test for AR(2) & Yes & Yes & Yes & $3.053^{* * *}$ \\
\hline Nes & $3.008^{* * *}$ & $3.119^{* *}$ & $3.105^{* * *}$ & $(1.044)$ \\
\hline
\end{tabular}

Note: Investor sentiments is the dependent variable. Values in parenthesis are the robust standard errors. Hansen J-test refers to the over-identification test for the restrictions in GMM estimation. The AR2 test is the Arellano-Bond test for the existence of the second-order autocorrelation in first differences. *, **, and *** indicate significance at the 10\%, 5\%, and $1 \%$ levels, respectively.

We also tested the moderating effect of investor sentiments on the relationship between active COVID19 cases and daily returns. Nonetheless, the insignificance of interaction term indicates that investor behavior acts as a mediator rather than a moderator on the relationship between coronavirus outbreak and stock returns. Consistent with prior studies, we find that air pollution is negatively associated with daily returns. Prior studies justified this relationship with mood deteriorations as air pollution increases the bodily level of cortisol and thereby induce pessimism and risk-aversion (Lepori, 2016; Li, \& Peng, 2016). Nonetheless, under the conditions of clean energy stocks and the COVID-19 outbreak, the situation could be different.

We believe that the floor trading community is most likely affected by air pollution compared to electronic system users (Lepori, 2016). Lockdown period and the ban of public gathering during coronavirus outbreak also restricted floor trading, thus, air pollution did not directly influence the mood or sentiments of investors. Nevertheless, it should also be noted that the COVID-19 crisis also crashed the oil prices (Albulescu, 2020) and imposed trade restrictions (Devi, 2020). Since previous studies found that the consumption of renewable energy decrease with the increase in oil prices and trade restrictions (Omri \& Nguyen, 2014; Yahya, \& Rafiq, 2019), countries relied on non-renewable energy sources during the pandemic, which enhances the air pollu- tion and decreases the demand for renewable energy sources.

Table 2 shows no evidence that temperature influences investor sentiments or stock returns. In the case of control variables, we find a positive effect of Turn-of-the-month on investor sentiments and significant effect of electricity consumption on the clean energy stock returns. The remaining control variables show no significant relationship with either investor sentiments or stock returns.

For robustness purposes, we differentiate the subpanels based on low-high air pollution and temperature. The results in Table 3 show that coronavirus cases negatively affect the investor sentiments regardless of frequency and intensity of meteorological conditions. Nonetheless, the calendar anomaly (i.e. TOM) does not affect investor sentiments when air pollution is low. The rest of the results are consistent with the main panel.

Table 4 shows that investor sentiments significantly influence stock returns regardless of low-high meteorological conditions. Additionally, active coronavirus cases negatively influence stock returns regardless of pessimistic or optimistic investor sentiments. However, air pollution does not significantly influence shareholder returns when investor sentiments are high. The risk-taking behavior induced by optimistic investor's sentiments degenerates the detrimental effect of air pollution as the increased trading activity builds a buoyant market for clean energy 
Table 4. Two-Step System GMM Estimations for Investor Sentiments Model

\begin{tabular}{|c|c|c|c|c|c|c|}
\hline & Low AIRP & High AIRP & Low TEMP & High TEMP & Low INS & High INS \\
\hline & 1 & 2 & 3 & 4 & 5 & 6 \\
\hline Daily Returns (t-1) & $\begin{array}{c}3.608 * * \\
(1.178) \\
\end{array}$ & $\begin{array}{c}3.702 * * \\
(1.159) \\
\end{array}$ & $\begin{array}{l}3.710^{*} \\
(1.053) \\
\end{array}$ & $\begin{array}{c}3.772 * * \\
(1.044)\end{array}$ & $\begin{array}{c}2.916^{* * *} \\
(1.182)\end{array}$ & $\begin{array}{l}3.299^{*} \\
(1.457)\end{array}$ \\
\hline Investor Sentiments & $\begin{array}{l}0.028^{*} \\
(0.007) \\
\end{array}$ & $\begin{array}{c}0.026 * * \\
(0.005) \\
\end{array}$ & $\begin{array}{c}0.022 * * \\
(0.008)\end{array}$ & $\begin{array}{c}0.024 * * \\
(0.011)\end{array}$ & & \\
\hline Active Cases & $\begin{array}{l}-0.001 \\
(0.001)\end{array}$ & $\begin{array}{c}-0.002 \\
(0.001)\end{array}$ & $\begin{array}{c}-0.002 \\
(0.001)\end{array}$ & $\begin{array}{c}-0.003 \\
(0.001) \\
\end{array}$ & $\begin{array}{c}-0.007 * * \\
(0.001)\end{array}$ & $\begin{array}{c}-0.001 * \\
(0.002) \\
\end{array}$ \\
\hline Air Pollution & & & $\begin{array}{l}-0.005^{*} \\
(0.001) \\
\end{array}$ & $\begin{array}{c}-0.006 * * \\
(0.001) \\
\end{array}$ & $\begin{array}{l}-0.005^{*} \\
(0.002) \\
\end{array}$ & $\begin{array}{c}-0.008 \\
(0.001) \\
\end{array}$ \\
\hline Temperature & $\begin{array}{c}0.015 \\
(0.009)\end{array}$ & $\begin{array}{c}0.017 \\
(0.007)\end{array}$ & & & $\begin{array}{c}0.011 \\
(0.007)\end{array}$ & $\begin{array}{c}0.013 \\
(0.005)\end{array}$ \\
\hline Weekend & $\begin{array}{c}0.911 \\
(0.053) \\
\end{array}$ & $\begin{array}{c}0.928 \\
(0.041) \\
\end{array}$ & $\begin{array}{c}0.917 \\
(0.070) \\
\end{array}$ & $\begin{array}{c}0.924 \\
(0.043) \\
\end{array}$ & $\begin{array}{c}0.895 \\
(0.021) \\
\end{array}$ & $\begin{array}{l}0.910^{*} \\
(0.092) \\
\end{array}$ \\
\hline TOM & $\begin{array}{c}0.005 \\
(0.002) \\
\end{array}$ & $\begin{array}{c}0.004 \\
(0.003) \\
\end{array}$ & $\begin{array}{c}0.003 \\
(0.001) \\
\end{array}$ & $\begin{array}{c}0.006 \\
(0.002) \\
\end{array}$ & $\begin{array}{c}0.007 \\
(0.001) \\
\end{array}$ & $\begin{array}{l}0.005^{*} \\
(0.003) \\
\end{array}$ \\
\hline Foreign Exchange & $\begin{array}{c}0.089 \\
(0.017)\end{array}$ & $\begin{array}{c}0.092 \\
(0.020) \\
\end{array}$ & $\begin{array}{c}0.084 \\
(0.016)\end{array}$ & $\begin{array}{c}0.089 \\
(0.014)\end{array}$ & $\begin{array}{c}0.091 \\
(0.018)\end{array}$ & $\begin{array}{c}0.094 \\
(0.021)\end{array}$ \\
\hline Electricity Consumption & $\begin{array}{l}1.803^{* *} \\
(0.094) \\
\end{array}$ & $\begin{array}{c}1.825 * * * \\
(0.097) \\
\end{array}$ & $\begin{array}{l}1.972 * * \\
(0.103) \\
\end{array}$ & $\begin{array}{l}1.990 * * \\
(0.095) \\
\end{array}$ & $\begin{array}{l}1.982^{*} \\
(0.109) \\
\end{array}$ & $\begin{array}{l}1.993 * * \\
(0.105) \\
\end{array}$ \\
\hline Month Dummy & Yes & Yes & Yes & Yes & Yes & Yes \\
\hline Country Dummy & Yes & Yes & Yes & Yes & Yes & Yes \\
\hline Sub-region Dummy & Yes & Yes & Yes & Yes & Yes & Yes \\
\hline Intercept & $\begin{array}{c}4.108 * * * \\
(1.815)\end{array}$ & $\begin{array}{c}4.095 * * \\
(1.776) \\
\end{array}$ & $\begin{array}{c}4.088 * * \\
(1.860)\end{array}$ & $\begin{array}{l}4.093 * \\
(1.742) \\
\end{array}$ & $\begin{array}{c}4.084 * * \\
(1.791) \\
\end{array}$ & $\begin{array}{c}4.078 * * \\
(1.961) \\
\end{array}$ \\
\hline Hansen J-test & 0.316 & 0.335 & 0.447 & 0.418 & 0.448 & 0.442 \\
\hline Arellano-Bond test for AR(2) & 0.894 & 0.905 & 0.914 & 0.903 & 0.936 & 0.928 \\
\hline
\end{tabular}

Note: Daily Stock Return is the dependent variable. Values in parenthesis are the robust standard errors. Hansen J-test refers to the over-identification test for the restrictions in GMM estimation. The AR2 test is the Arellano-Bond test for the existence of the second-order autocorrelation in first differences. $*, * *$ and $* * *$ indicate significance at the $10 \%, 5 \%$, and $1 \%$ levels, respectively.

stocks. Lastly, we find the calendar anomalies are significant when investor sentiments are high. This evidence is in line with Stambaugh et al. (2012) that behavioral anomalies are generally high during bullish trends.

\section{Conclusion}

Clean energy stocks are generally viewed as sustainable and less vulnerable to external shocks. However, the returns of renewable energy stocks also decline in the wake of the coronavirus outbreak in the Asian-Pacific region. Our results show that investor sentiments are the transmission channel for the detrimental effect of COVID-19 outbreak on stock returns. Our investigation also leads us to indicate the negative effect of air pollution on clean energy stock returns. We conjectured that this negative relationship is not because of the psychological reasons but due to reliance of economies on non-renewable energy sources with a decrease in oil prices and trade openness. Nevertheless, this link can deteriorate with the buoyant market and optimistic investor sentiments.

We acknowledge that our study has certain limitations and future studies are needed to overcome them. First, the empirical model is not applied to the pre-coronavirus period to compare the results related to investor sentiments and meteorological conditions. Second, only $\mathrm{PM}_{2.5}$ is utilized to measure air pollution. Considering AQI or other air pollution proxies may produce different estimates. Third, we have ignored other meteorological conditions such as humidity, wind pressure, etc. Better estimates can be generated when these weather-related proxies will be tested with their related industries, e.g. the effect of wind pressure on wind turbine producers' stocks or temperature on solar panel producers.

Although there is still uncertainty related to COVID19 crises, our study provides several implications for policymakers and responsible investments. Investors are advised to hold their clean energy stocks as markets will be able to adjust the short-term anomalies caused by investor sentiments due to coronavirus outbreak. Furthermore, the detrimental effects of air pollution on mental and physical health were already known (Lepori, 2016; Yahya \& Rafiq, 2020), researchers have also proved that the exposure of air pollution is linked with increased risk of COVID-19 infection (Yongjian, Jingu, Fengming, \& Liqing, 2020). Since the reliance on fossil fuels has exposed the countries to the health crisis and economic shocks, the use of clean energy sources will be preferred in the future. Besides the greenness effect of renewable energy stocks, it is expected that they may provide stability of cash flows from underlying assets. 


\section{References}

1. AKHTARUZZAMAN M., BOUBAKER S., SENSOY A., 2020, Financial contagion during COVID19 crisis, in: Finance Research Letters, 101604.

2. AL-AWADHI A. M., AL-SAIFI K., AL-AWADHI A., ALHAMADI S., 2020, Death and contagious infectious diseases: Impact of the COVID-19 virus on stock market returns, in: Journal of Behavioral and Experimental Finance, 100326.

3. ALBULESCU C., 2020, Coronavirus and oil price crash, in: SSRN 3553452.

4. ALBUQUERQUE R., KOSKINEN Y., YANG S., ZHANG C., 2020, Resiliency of environmental and social stocks: an analysis of the exogenous COVID19 market crash, in: The Review of Corporate Finance Studies, cfaa011.

5. ALI M., ALAM N., RIZVI S. A. R., 2020, Coronavirus (COVID-19) - An epidemic or pandemic for financial markets, in: Journal of Behavioral and Experimental Finance, 100341

6. ALONSO-BORREGO C., ARELlANO M., 1999. Symmetrically normalized instrumental-variable estimation using panel data, in: Journal of Business \& Economic Statistics, 17(1), p. 36-49.

7. APERGIS N., GABRIELSEN A., SMALES L. A., 2016, (Unusual) weather and stock returns - I am not in the mood for mood: further evidence from international markets, in: Financial Markets and Portfolio Management, 30(1), p. 63-94.

8. ASHRAF B. N., 2020, Stock markets' reaction to COVID-19: cases or fatalities?, in: Research in International Business and Finance, 101249.

9. BAKER M., WURGLER J., 2006, Investor sentiment and the cross-section of stock returns, in: The journal of Finance, 61(4), p. 1645-1680.

10. BALTAGI B. H. (ed.), 2015, The Oxford handbook of panel data, Oxford Handbooks.

11. BI J., ZHU Y., 2020, Value at risk, cross-sectional returns and the role of investor sentiment, in: Journal of Empirical Finance, 56, p. 1-18.

12. BIROL F., 2020, The coronavirus crisis reminds us that electricity is more indispensable than ever, International Energy Agency.

13. BLUNDELL R., BOND S., 1998, Initial conditions and moment restrictions in dynamic panel data models, in: Journal of econometrics, 87(1), p. 115-143.

14. BOURDEAU-BRIEN M., KRYZANOWSKI L., 2017, The impact of natural disasters on the stock returns and volatilities of local firms, in: The Quarterly Review of Economics and Finance, 63, p. 259-270.

15. COHEN M. J., 2020, Does the COVID-19 outbreak mark the onset of a sustainable consumption transition?, in: Sustainability: Science, Practice and Policy, 16(1).

16. COIBION O., GORODNICHENKO Y., WEBER M., 2020, The Cost of the COVID-19 Crisis: Lockdowns, Macroeconomic Expectations, and Consumer Spending (No. w27141), National Bureau of Economic Research.

17. CROSS F., 1973, The behavior of stock prices on Fridays and Mondays, in: Financial analysts journal, 29(6), p. 67-69.

18. DEVI S., 2020, Travel restrictions hampering COVID-19 response, in: The Lancet, 395(10233), p. 1331-1332.
19. DING X., GUO M., YANG T., 2020, Air Pollution, Local Bias, and Stock Returns, in: Finance Research Letters, 101576.

20. DOWLING M., LUCEY B. M., 2008, Robust global mood influences in equity pricing, in: Journal of Multinational Financial Management, 18(2), p. 145-164.

21. FLOROS C., 2011, On the relationship between weather and stock market returns, in: Studies in Economics and Finance, 28(1), p. 5-13.

22. HENS T., RIEGE M. O., 2016, Financial economics: A concise introduction to classical and behavioral finance, Springer, New York.

23. ICHEV R., MARINC M., 2018, Stock prices and geographic proximity of information: Evidence from the Ebola outbreak, in: International Review of Financial Analysis, 56, p. 153-166.

24. IEA, 2020, Covid-19 impact on electricity, httpps:// www.iea.org/reports/covid-19-impact-on-electricity, (1.09.2020).

25. KAMSTRA M. J., KRAMER L. A., LEVI M. D., 2000, Losing sleep at the market: The daylight saving anomaly, in: American Economic Review, 90(4), p. 1005-1011.

26. KANDA W., KIVIMAA P., 2020, What opportunities could the COVID-19 outbreak offer for sustainability transitions research on electricity and mobility?, in: Energy Research \& Social Science, 68, 101666.

27. KAPLANSKI G., LEVY H., 2010, Sentiment and stock prices: The case of aviation disasters, in: Journal of Financial Economics, 95(2), p. 174-201.

28. LEPORI G. M., 2016, Air pollution and stock returns: Evidence from a natural experiment, in: Journal of Empirical Finance, 35, p. 25-42.

29. LI Q., PENG C. H., 2016, The stock market effect of air pollution: evidence from China, in: Applied Economics, 48(36), p. 3442-3461.

30. LIU H., MANZOOR A., WANG C., ZHANG L., MANZOOR Z., 2020, The COVID-19 Outbreak and Affected Countries Stock Markets Response, in: International Journal of Environmental Research and Public Health, 17(8), 2800.

31. MCGURK Z., NOWAK A., HALL J. C., 2020, Stock returns and investor sentiment: textual analysis and social media, in: Journal of Economics and Finance, 44, p. 458-485.

32. MYLENKA T., NOVYK B., 2020, Impact of Covid19 on the global energy sector, in: PV Magazine, https://www.pv-magazine.com/2020/04/24/impactof-covid-19-on-the-global-energy-sector/ (1.09.2020).

33. OMRI A., NGUYEN D. K., 2014, On the determinants of renewable energy consumption: International evidence, in: Energy, 72, p. 554-560.

34. PAPAKYRIAKOU P., SAKKAS A., TAOUSHIANIS Z., 2019, The impact of terrorist attacks in G7 countries on international stock markets and the role of investor sentiment, in: Journal of International Financial Markets, Institutions and Money, 61, p. 143160.

35. QIANG Z., SHU-E, Y., 2009, Noise trading, investor sentiment volatility, and stock returns, in: Systems Engineering-Theory \& Practice, 29(3), p. 40-47. 
36. ROODMAN D., 2009, A note on the theme of too many instruments, in: Oxford Bulletin of Economics and statistics, 71(1), p. 135-158.

37. SEOK S. I., CHO H., RYU D., 2019, Firm-specific investor sentiment and daily stock returns, in: The North American Journal of Economics and Finance, 50, 100857.

38. SHEIKH M. F., SHAH S.Z.A., MAHMOOD S., 2017, Weather effects on stock returns and volatility in South Asian markets, in: Asia-Pacific Financial Markets, 24(2), p. 75-107.

39. SOHRABI C., ALSAFI Z., O'NEILL N., KHAN M., KERWAN A., AL-JABIR A., AGHA R., ET AL., 2020, World Health Organization declares global emergency: A review of the 2019 novel coronavirus (COVID-19), in: International Journal of Surgery, 76, p. 71-76.

40. WOOLDRIDGE J. M., 2010, Econometric analysis of cross section and panel data, MIT press.
41. WU Q., HAO Y., LU J., 2018, Air pollution, stock returns, and trading activities in China, Pacific-Basin Finance Journal, 51, p. 342-365.

42. YAHYA F., RAFIQ M., 2019, Unraveling the contemporary drivers of renewable energy consumption: Evidence from regime types, in: Environmental Progress \& Sustainable Energy, 38(5), 13178.

43. YAHYA F., RAFIQ M., 2020, The Influence of Air Pollution and Clean Energy on Tuberculosis: The Moderating Role of Urbanization, in: Iranian Journal of Public Health, 49(6), p. 1106-1111.

44. YONGJIAN Z., JINGU X., FENGMING H., LIQING C., 2020, Association between short-term exposure to air pollution and COVID-19 infection: Evidence from China, in: Science of the total environment, 138704.

45. ZHANG D., HU M., JI Q., 2020, Financial markets under the global pandemic of COVID-19, in: Finance Research Letters, 101528. 
